\title{
Urban Resilience to Flooding: Triangulation of Methods for Hazard Identification in Urban Areas
}

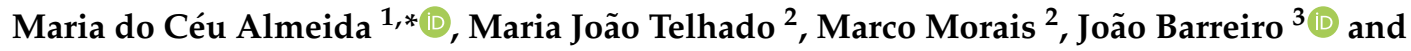 \\ Ruth Lopes 4 \\ 1 Urban Water Unit, National Civil Engineering Laboratory, LNEC, Av. Brasil 101, 1700-066 Lisbon, Portugal \\ 2 Lisbon City Council, Câmara Municipal de Lisboa, CML, Praça José Queirós, n. ${ }^{\circ} 1-3^{\circ}$ piso - Fração 5, \\ 1800-237 Lisboa, Portugal; joao.telhado@cm-lisboa.pt (M.J.T.); marco.morais@cm-lisboa.pt (M.M.) \\ 3 CEris, Instituto Superior Técnico, University of Lisbon, Av. Rovisco Pais, 1049-001 Lisboa, Portugal; \\ joao.barreiro@tecnico.ulisboa.pt

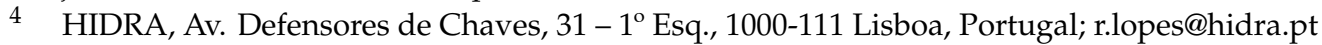 \\ * Correspondence: mcalmeida@lnec.pt
}

Received: 31 January 2020; Accepted: 10 March 2020; Published: 12 March 2020

\begin{abstract}
The effects of climate dynamics on urban areas involve the aggravation of existing conditions and the potential for emergence of new hazards or risk factors. Floods are recognized as a leading source of consequences to society, including disruption of critical functions in urban areas, and to the environment. Consideration of the interplay between services providers ensuring urban functions is essential to deal with climate dynamics and associated risks. Assessment of resilience to multiple hazards requires integrated and multi-sectoral approaches embracing each strategic urban sector and interactions between them. A common limitation resides in the limited data and tools available for undertaking these complex assessments. The paper proposes a methodology to undertake the spatial characterization of the flood related hazards and exposure of both essential functions and services providers in urban areas, in the context of limitations in data and in ready-to-use tools. Results support the resilience assessment of these hazards, taking into account interdependencies and cascading effects. The approach is applied to Lisbon city as the study case. Results are promising in demonstrating the potential of combining data and knowledge from different sources with dual modelling approaches, allowing us to obtain trends on the magnitude of effects of climate scenarios and to assess potential benefits of adaptation strategies. Quantification of the effects is reached, but results need to be assessed together with the underlying levels of uncertainty. The methodology can facilitate dialogue among stakeholders and between different decision levels.
\end{abstract}

Keywords: climate change; flooding; hazard mapping; risk identification; sustainability; urban resilience

\section{Introduction}

Comprehensive understanding of the vision for urban areas encompasses a number of widely used concepts. The concepts of sustainability, resilience, adaptability, safety, transformation and liveability are more or less implicit as main guidelines for action [1,2], even if the understanding of these concepts is not generalized and is often vague or narrow [3]. Translation of these concepts into development strategies for the complex and dynamic urban systems can be an unreachable aim. However, as emphasized in Reference [3], "cities have proven to be remarkably resilient complex systems: many cities have existed for thousands of years and have persevered in the face of natural and human-induced disasters to become stronger and in some cases more resilient". Despite these debates, there is a need for a shift to a more sustainable and resilient path [1]. 
Aligned with this vision, and aware of the challenges that climate change imposes on urban areas, the option of dealing with specific associated hazards, while ensuring the involvement of multiple urban services and interested parties, allows for reducing the dimension of the problem.

Water related risks are amongst those that are significantly dependent on climate related events. The intrinsic dynamic nature of climate in each region already challenges the managers of urban systems. Climate change effects on the urban areas potentially aggravate existing conditions and lead to the emergence of new hazards or risk factors. Floods are a leading source of adverse consequences for urban areas $[4,5]$.

City resilience, understood as the ability to absorb, adapt and recover from disruptive events in a path towards increasing sustainability [6], provides a broad conceptual structure to assess and support planning in urban areas. Any integrated and sustainable approach to increase resilience needs to be supported by sound knowledge. However, the complexity and dynamics of urban areas imply the acceptance of several limitations on data, tools and resources. Planning for increasing resilience can benefit from the use of diverse information and methods to add reliability and validity to the results. Furthermore, explicit consideration of uncertainties of climate phenomena and meteorological events [7] is critical, even if quantification is not always feasible.

Focusing on the water sector, events such as intense rainfall, storm surge, sea level rise and temperature increase are of concern in urban areas. Aggravation of these climate conditions has the potential to increase the likelihood and consequences of severe events, as well as to reduce the performance of urban water systems during less extreme conditions [7]. Cities and services providers must be prepared to cope with these challenges. The interplay between services providers, ensuring urban functions, is essential to face climate related events and to assess the resilience to multiple hazards. This requires an integrated and multi-sectoral approach taking into account strategic urban sector and their interactions [8-10], but significant gaps have been found in risk-based approaches [11]. As emphasized by Reference [9], conceptual approaches based solely on vulnerability and precaution are limited and the adoption of the concept of resilience as a new paradigm allows for the implementation of more integrated risk management in a systemic manner (p.237).

Cities and towns rely on water systems, some incorporating components built over 200 years ago, built gradually following population growth. These systems are functional and represent a high asset value. Rehabilitation rates are already lower than needs today and expectations are for continued deterioration and low investments [12], especially in sewerage. Service failures affect society, for instance, whenever volumes exceed transport, treatment or storage capacities, and excess water often results in flooding. Consequences of flood events are multidimensional, including adverse effects on the water services, health and safety of populations, socio-economy and environment. Mobility, wastes and electricity supply are some of the sectors often affected by flooding and potentially propagating their effects $[8,11,13-16]$.

Assessment of resilience and selection of options to improvement depends on two key steps [17,18]: characterization of flood events, which determines exposed assets and population; and estimation of vulnerability to allow estimating magnitude of damages for specific types of events. Limitations on risk identification determine the robustness of subsequent analysis, from exposure to impacts estimation.

The work presented herein is part of a broader approach (RESCCUE: Resilience to cope with climate change in urban areas - a multisectorial approach focusing on water project) to enable city resilience assessment, planning and management by incorporating new and existing knowledge of the urban systems performance under climate change conditions in a water-centred multi-risk assessment of strategic urban services performance using a comprehensive resilience platform [10]. The assessment of urban resilience from a multisector approach is carried out for current and future climate scenarios, and includes multiple risks.

Sound assessment of the resilience to flooding requires the systematic identification of risks and corresponding hazards, risk factors and risk sources for dealing with current and expected future levels of risk in order to increase the resilience of cities, using the available information. This paper 
presents the developments in terms of risk identification related with climate change effects and services interdependencies, specifically for flood related hazards. The approach aims at setting a practicable methodology in a background of limitations in data and in ready-to-use tools using the city of Lisbon as a study case, including the spatial characterization of these hazards. The results are essential to supporting the assessment of the resilience to these hazards of essential urban functions such as mobility, wastes management and electricity supply, taking into account interdependencies and cascading effects. The paper details developments relevant for the mobility and wastes management sectors. The electrical sector, deemed essential for the city, has a Quality Service Zone Type A for the design and planning of the network, implying the existence of incremental layers of resilience and the robustness of the grid, while minimizing the impact in case of disruption. A Type A Zone has high-level redundancy in the electricity supply service [19].

\section{Lisbon City Overview}

Lisbon, the capital of Portugal, is one of 18 the municipalities of the biggest Portuguese metropolitan area and has the second largest European port on the Atlantic Ocean. Lisbon is a city shaped by influences of a large number of cultures over time and by the extensive riverfront on the river Tagus estuary. Characteristic figures for Lisbon city are listed in Table 1 . The city has a temperate climate, classified as Mediterranean climate (Köppen climate classification: Csa), characterized by dry and hot summers and wet and fresh winter periods.

Climate change trends for Lisbon include the increase in average air temperature, decrease in annual and non-wet season rainfall, increase in wet-season rainfall and in intense rainfall events frequency, average sea level rise and increase of coastal floods frequency. The combined action of intense rainfall, wind, sea level rise with tides and storm surges is especially relevant for Lisbon's context and geographical position.

Table 1. Lisbon city characteristics [20-22].

\begin{tabular}{|c|c|c|c|c|}
\hline Area $\left(\mathrm{Km}^{2}\right)$ & & 85 & Economic indicators (2013) & \\
\hline \multirow{3}{*}{$\begin{array}{l}\text { Population } \\
\text { (2011) } \\
\text { (inhab.) }\end{array}$} & Residents & 547,733 & GDP (millions of euros) & 63,902 \\
\hline & Commuters balance & $+378,226$ & $\begin{array}{l}\text { Gross value added GVA (millions } \\
\text { of euros) }\end{array}$ & 56,154 \\
\hline & Disabled (\%) & 17.1 & GDP per capita (thousands of euros) & 22.7 \\
\hline \multirow{5}{*}{$\begin{array}{l}\text { Tourism } \\
\text { (2011) } \\
\text { Age } \\
\text { distribution } \\
\text { Land slope } \\
\text { Altitude (m) }\end{array}$} & $\begin{array}{l}\text { tourists/year } \\
\text { tourist nights/year }\end{array}$ & $\begin{array}{l}2,949,579 \\
6,789,166\end{array}$ & $\begin{array}{l}\text { Apparent labour productivity (per person } \\
\text { employed) (GVA/Employment, 2011) }\end{array}$ & 41.7 \\
\hline & $<15$ years old & $12.9 \%$ & Employment indicators, 2011 & \\
\hline & $>65$ years old & $23.9 \%$ & Employment (thousands of persons) & $1,385.8$ \\
\hline & Average: $5.7^{\circ}$ & Maximum: $81^{\circ}$ & Employment (\% country) & $29 \%$ \\
\hline & Minimum: 0 & Maximum: 217 & Water distribution service connections & $\approx 80,000$ \\
\hline \multirow{3}{*}{$\begin{array}{l}\text { Land use } \\
\text { values }\end{array}$} & Consolidated urban & $90 \%$ & Wastewater infrastructures & \\
\hline & Buildings (n.) & 52,496 & Combined sewer network served area (\%) & 73 \\
\hline & Vehicles/day (2012) & 648,615 & Treatment plants & 3 \\
\hline
\end{tabular}

The Municipality is involved and proactively committed to increase the resilience of the city to achieve the 17 Sustainable Development Goals by actively working in relevant areas such as participating in international initiatives such as C40 and 100 Resilient Cities, largely investing from strategic to practical actions to increase city sustainability [23,24].

\section{Methodology and Data}

\subsection{Methodology Main Steps}

The overall methodology proposed to undertake the spatial characterization of the flood related hazards has the following main steps: 
(i) Identification of flood related hazards, risk factors and risks using the selected affected sectors as case studies, namely, electricity supply, urban mobility and wastes collection.

(ii) Selection of metrics for hazards characterization and mapping.

(iii) Selection of representative scenarios to characterize current and future situations.

(iv) Mapping of hazards and calculation of metrics to support further work on resilience assessment using GIS.

The methodology adopted for hazards identification takes the data obtainable for the investigation and available tools into consideration to diagnose and evaluate the effect of climate change scenarios in terms of flood related hazards as a route to ascertain resilience of urban services to these events. Both data and models have inherent limitations and uncertainties and research design is grounded on the use of complementary methods, in a triangulation-based approach [25], using multiple methods to study the research problem [26]. Methodological triangulation allows adding reliability and validity to the results and cross checking of results [27], taking advantage of overlapping and intersecting layers of geographic information. For the study case of Lisbon, the set of methods, available for the triangulation to support flood risk identification, are identified. The structure adopted in this study is given in Figure 1.

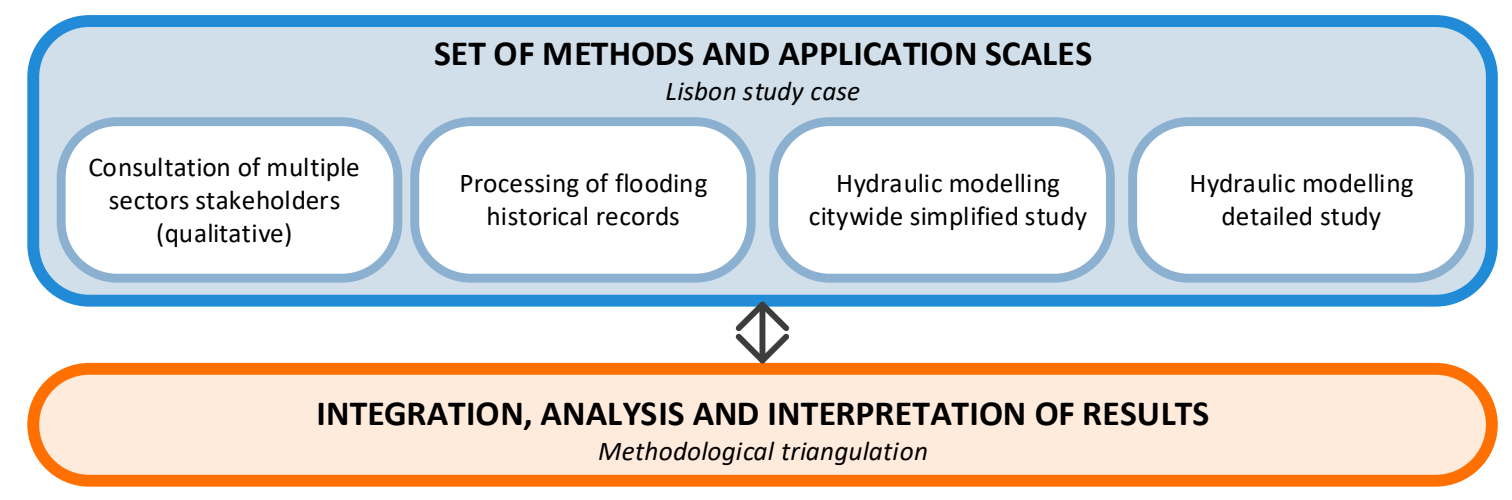

Figure 1. Methods triangulation for characterization and mapping of flooding related hazards.

Assumptions in this study include the focus on the water cycle and flood related hazards, while the risk sources analysed are rainfall and coastal overtopping [10]. The emphasis here is on the mobility and waste management sectors, but the methodology is applicable to other urban sectors.

\subsection{Tools and Data to Support Risk Identification}

The first step is to identify the data and tools available for the study case to support the methodology refinement; the methodology takes into account current and future situations while considering climate change.

In terms of tools, two types of hydraulic mathematical models are available for the city of Lisbon [28,29]: (1) the City wide 1D GIS model; (2) the Downtown catchments JL using 1D/2D combined model (SWMM and Basement) [30,31]. These models have a number of limitations in the data for model building and confirmation, but the two models do represent a balance between spatial scope, level of detail and data availability. The former (1) covers the city as a whole but adopts a simplified hydraulic model and sewer network; the later (2) uses a more robust hydraulic formulation and includes network as well as overland flow simulation.

For the study case of Lisbon, the set of methods available to support description and mapping of flood related hazards are indicated in Figure 2, together with main outputs and hazard characteristics.

The approach adopted in method 1, a qualitative method, allows for collaborative crosscheck, where groups or individuals with different points of view investigate common issues involving interrelated systems and services, increasing the validation and consolidation of the aspects 
evaluated [32]. With this approach, identification of flood related hazards and risk factors for strategic urban services was developed in a collaborative process involving representatives of the Lisbon city services included in the study. Stakeholders with direct involvement are listed in Table 2. Following the consultation sessions with stakeholders, the analysis of results for the study case resulted in an interdependencies matrix. The structure and aims of the study and focus on issues related to flooding in this specific city has determined the level of involvement of the stakeholders.

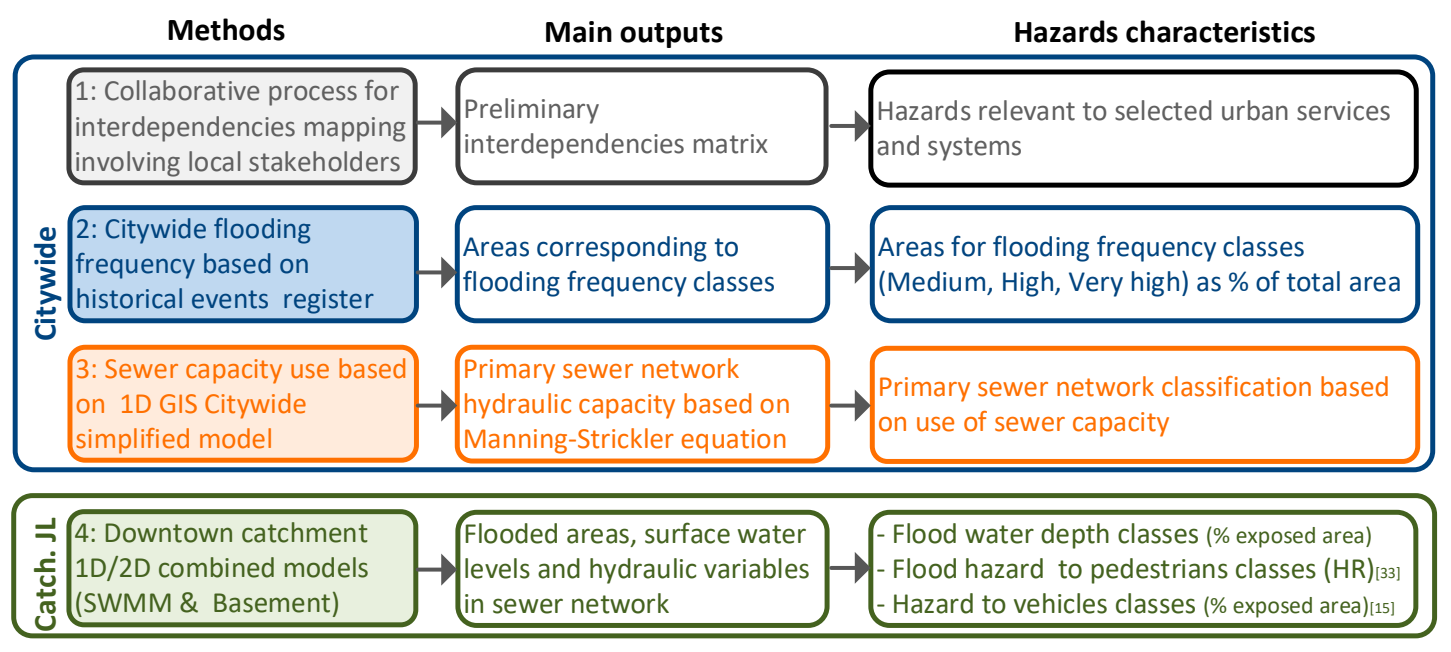

Figure 2. Methods for characterization and mapping of flood related hazards and outputs.

Table 2. Main stakeholders involved in the Lisbon city study case.

\begin{tabular}{lll}
\hline Service & Stakeholders & Level of Involvement \\
\hline Municipality & Lisbon Municipality (CML) & High \\
Energy supply & Distribution System Operator (EDP D) & High \\
Rain and wastewater systems & CML and ADTA & High \\
Water supply & EPAL & Low \\
Public transport & CML, CARRIS, METRO & Medium \\
Communications & MEO Altice, Vodafone, NOS & Low \\
\hline
\end{tabular}

* Includes a range of urban services, e.g., civil protection, wastes, public lighting, urban planning, mobility and environment.

For method 2, data from a historical events register, currently updated by the civil protection services, was used to assess citywide flood frequency.

In method 3, the citywide model approach (1) the hydraulic modelling simplified study of the drainage system (1D GIS model), was based on a conceptual model due to the complexity of Lisbon's drainage system and data limitations. This simulation tool uses GIS routines and was implemented on ArcMap ${ }^{\mathrm{TM}}$ software. This model was built with the primary sewer network, to enable modelling of major physical and hydrodynamic properties of the system. This model includes 421 sub-catchments, 797 junctions and 753 sewers, which make up a total of $173 \mathrm{~km}$, around $12 \%$ of the whole sewer network length. From the 797 junctions, 218 are head junctions and 48 are final junctions, which discharge to a main trunk system (primary sewer conveying wastewater to the treatment plant), the Tagus River (receiving water body) or to neighbouring councils' sewers. Secondary sewers (cross-sections smaller than $800 \mathrm{~mm}$ ) are not included.

In method 4, for the Lisbon Downtown catchments J-L, the 1D/2D SWMM and BASEMENT combined model was set to allow for estimating the flooded areas and its water levels at the surface. These catchments were selected because they are two of the most flood prone catchments in Lisbon, encompassing historical and touristic downtown areas with relevant infrastructure and services. The 
model for this area includes 32 sub-catchments, 331 sewers and 318 nodes, from which six corresponded to outfalls $[28,29]$.

\subsection{Selection of Metrics for Hazards Characterization and Mapping}

Depending on the available information and model used, different criteria are applicable, resulting in a more comprehensive understanding of the hazards. The urban functions selected to illustrate the application of this methodology are those related to urban mobility and wastes collection.

In Table 3, a summary of metrics selected for flood related hazards for different approaches and scenarios is given.

Table 3. Definition of flood related hazards for different approaches and scenarios.

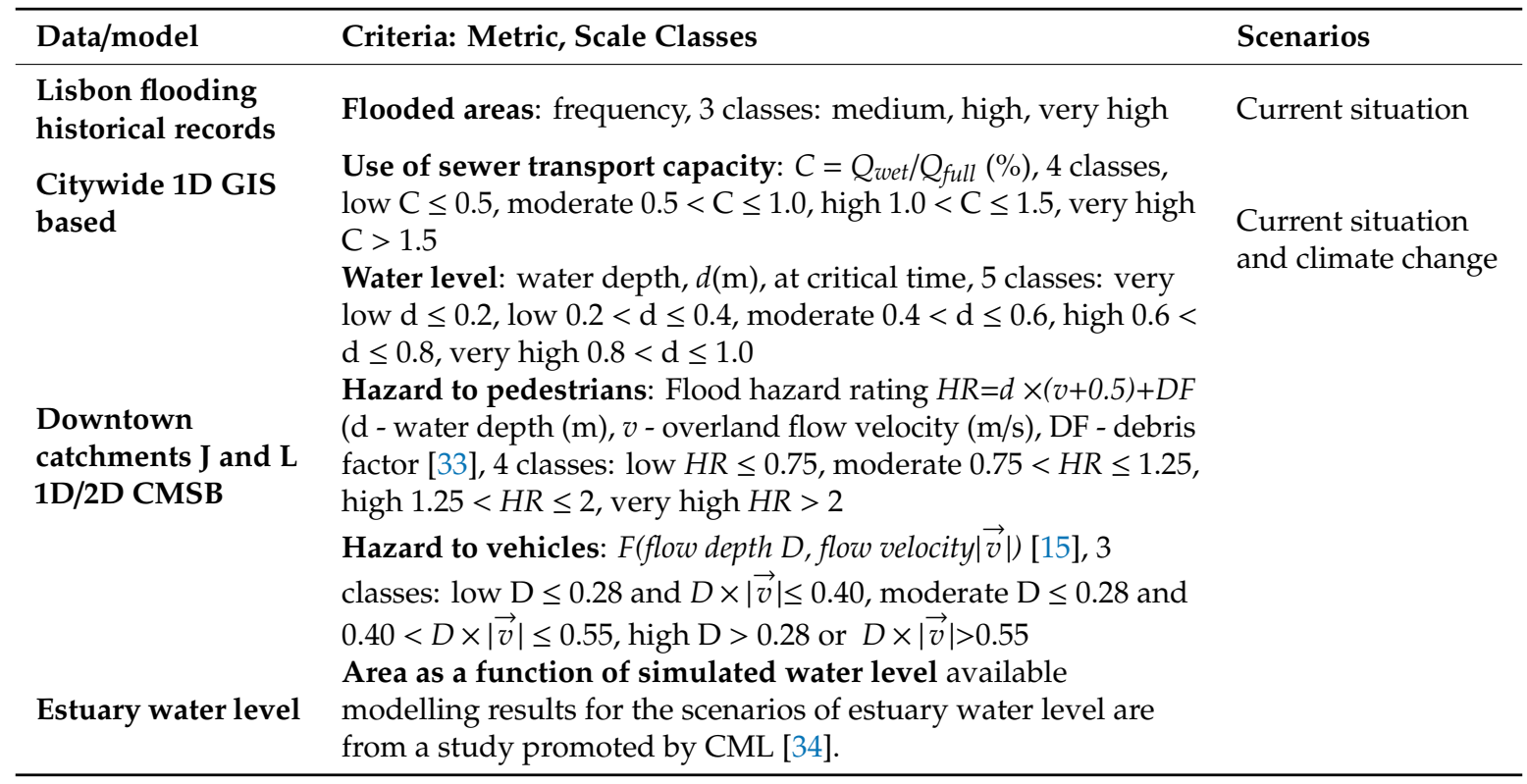

For the current situation, the historical data on flood events allowed obtaining hazard maps with areas as a function of flooding frequency, used to cross-validate the results from the simulations. A systematic recording of water levels was not undertaken and information on the water levels reached in each flood event is not available. For surface flows, the water level metric allowed for evaluation of consequences in properties.

\subsection{Selection of Representative Scenarios}

The selection of representative scenarios took two aspects into account: the infrastructure and climate. For the former, two situations were analysed: existing infrastructure and adaptation strategies (CAS, or climate adaptation strategy). For the latter, two situations were studied: the current situation and a future situation where climate change is accounted for. From the results of available studies on climate change to Lisbon, to characterize current situation and climate change [34,35], representative scenarios were selected, for both the current situation and future situation, for rainfall and for Tagus river estuary levels. These scenarios are aligned with those used by the Municipality for climate adaptation planning purposes.

For both climate situations, three return periods were selected (10 years, 20 years and 100 years) to take into account the variations in precipitation intensity. The actual values for existing infrastructure with climate change were defined as relative changes to current situation values. To limit the number of hydraulic simulations, an average estuary water level was adopted for each climate situation. The reference period for the future situation taking climate change into account is 2071-2100 (worst-case scenario). 
Three scenarios were analysed and compared: CS, used as the baseline, with the current system and climate characteristics; BAU, business as usual (for the system) assuming a future situation with climate change; and CAS, a future situation including the implementation of selected strategies for climate adaptation and assuming climate change scenarios.

\subsection{Mapping of Hazards and Data for Calculation of Global Metrics for Resilience Assessment}

The mapping of flood related hazards and calculation of metrics to be used as input to resilience assessment was carried out using the municipality GIS and data from several city databases. The global metrics adopted depended on the information available, but essentially consisted of aggregation by length and area, number or aggregated values for the variables used.

\section{Results and Discussion}

\subsection{Preliminary Interdependencies Matrix}

The broad identification of interdependencies in the city of Lisbon considers seven main urban services or infrastructure for which a matrix of exposure and interdependencies was developed: electricity supply; telecommunications; water cycle; wastes; mobility; green and blue infrastructure; urban equipment; public lighting; and heritage areas. A simplified version of the matrix is presented in Table 4. Systematic analysis took several urban services into consideration, including plausible cascading events. Globally, runoff and flooding can directly or indirectly affect most services and infrastructure.

\subsection{Main Results for Processing of Flooding Historical Records and Comparison with CS Simulation Results}

The results of the processing of historical records for the three return periods compared with the results of the model (1) simulations for current situation (CS as baseline) (Figure 3, for T=100 years) allow cross validating the results. Overall, the simulation results match with historical records for flood prone areas, especially for those near the river Tagus or areas where floods are more severe. As is evident from Figure 3, simulation results using a simplified network with only primary sewers do not provide full spatial coverage, with some areas with historical records likely to be associated with secondary sewers or rainwater inlets insufficiency. Additional model limitations such as simplified hydraulics, and the eventual occurrence of sedimentation and blockages not represented in the model, explain the apparent spare flow capacity in areas where flooding occurs regularly.

Historical records provide valuable information since the areas for each class of flood frequencies incorporate several records associated with each event and an extensive number of observations, and represent a proxy of the area for each flood frequency. 
Table 4. Summary interdependencies matrix for Lisbon urban services and infrastructures (R: rain; W: wind; SLR: sea level rise; WWTP: Wastewater treatment plants).

\begin{tabular}{|c|c|c|c|}
\hline SERVICE|SUBSYSTEM|Component & $\begin{array}{l}\text { SERVICE OR } \\
\text { INFRASTRUCTURE FAILURE }\end{array}$ & $\begin{array}{l}\text { EXPOSURE } \\
\text { TO }\end{array}$ & POTENTIAL DERIVED RISKS AND CASCADING EFFECTS \\
\hline $\begin{array}{l}\text { Energy | Electricity transport and } \\
\text { distribution I Substations, overhead } \\
\text { lines, underground cables }\end{array}$ & $\begin{array}{l}\text { Damages, collapse, interruption } \\
\text { of energy supply }\end{array}$ & $\begin{array}{l}\text { R: flood } \\
\text { W: storms }\end{array}$ & $\begin{array}{l}\text { Water supply: failures of electromechanical and control systems; Urban } \\
\text { drainage: failures of pumping and control systems; WWTP: failures of } \\
\text { electromechanical elements and control systems; Street lights: failures } \\
\text { regarding function and control systems; Communications: cellular towers, } \\
\text { central offices, other critical communications for monitoring and controlling } \\
\text { electricity delivery }\end{array}$ \\
\hline $\begin{array}{l}\text { Communications | Network and } \\
\text { nodes (operational centres) }\end{array}$ & $\begin{array}{l}\text { Damage, collapse, interruption of } \\
\text { communications }\end{array}$ & $\begin{array}{l}\text { R: runoff, flood } \\
\text { W: storms }\end{array}$ & Effects on several urban services depending on communications \\
\hline $\begin{array}{l}\text { Urban water cycle | Wastewater and } \\
\text { rainwater systems | Sewer systems }\end{array}$ & $\begin{array}{l}\text { Limited conveyance capacity, } \\
\text { high street runoff (level and } \\
\text { velocity), CSOs }\end{array}$ & $\begin{array}{l}\text { SLR; R: Rain: } \\
\text { high inflows, } \\
\text { runoff }\end{array}$ & $\begin{array}{l}\text { Mobility (road, rail): disturbance and interruptions, flooding of } \\
\text { underground infrastructures (metro, train, parking, tunnels); Wastes: } \\
\text { overturn, dragging and damage on wastes; Electrical energy: damage to } \\
\text { equipment and lines } \\
\text { Other: pedestrian ways, parking lots, playgrounds, CSOs }\end{array}$ \\
\hline $\begin{array}{l}\text { Urban water cycle | Wastewater and } \\
\text { rainwater systems | Pump stations }\end{array}$ & $\begin{array}{l}\text { Electrical or mechanical failures } \\
\text { due to flooding (pumping } \\
\text { capacity and CSO), salinity } \\
\text { degrading components, excessive } \\
\text { inflows }\end{array}$ & $\begin{array}{l}\text { SLR; R: high } \\
\text { inflows, runoff, } \\
\text { flood }\end{array}$ & $\begin{array}{l}\text { Mobility: traffic disturbances and interruptions; flooding of underground } \\
\text { infrastructures (metro, train, parking, tunnels) } \\
\text { Receiving water pollution; Recreational uses affected }\end{array}$ \\
\hline $\begin{array}{l}\text { Urban water cycle | Wastewater and } \\
\text { rainwater systems | WWTP }\end{array}$ & $\begin{array}{l}\text { Lower treatment efficiency and } \\
\text { CSO due to excessive flows and } \\
\text { dilution; lower treatment } \\
\text { efficiency and corrosion of } \\
\text { infrastructures by salt water } \\
\text { intrusion }\end{array}$ & $\begin{array}{l}\text { SLR; R: high } \\
\text { inflows, flood }\end{array}$ & $\begin{array}{l}\text { Receiving water pollution } \\
\text { Recreational uses affected }\end{array}$ \\
\hline $\begin{array}{l}\text { Wastes collection | Cleaning, } \\
\text { containers }\end{array}$ & $\begin{array}{l}\text { Container damage, displacement } \\
\text { and overturn }\end{array}$ & \multirow{3}{*}{$\begin{array}{l}\text { R: runoff, flood } \\
\text { W: storms } \\
\text { SLR; R: runoff, } \\
\text { flood; W: } \\
\text { storms } \\
\text { R: runoff, } \\
\text { flood; W: } \\
\text { storms }\end{array}$} & $\begin{array}{l}\text { Urban drainage: obstruction of components and surface flows } \\
\text { Mobility (road, rail): traffic disturbances and interruptions }\end{array}$ \\
\hline $\begin{array}{l}\text { Mobility | Roadways | Main roads, } \\
\text { secondary roads, tunnels }\end{array}$ & $\begin{array}{l}\text { Runoff, flooding and windstorm: } \\
\text { disruption, interruption of } \\
\text { mobility functions }\end{array}$ & & \multirow{2}{*}{$\begin{array}{l}\text { Several urban services can be affected by cascading effects if maintenance or } \\
\text { repair tasks are required during failures }\end{array}$} \\
\hline Mobility | Roadways |Traffic signs & $\begin{array}{l}\text { Wind can generate failures of } \\
\text { traffic control systems }\end{array}$ & & \\
\hline
\end{tabular}


Table 4. Cont.

\begin{tabular}{|c|c|c|c|}
\hline SERVICE|SUBSYSTEM|Component & $\begin{array}{l}\text { SERVICE OR } \\
\text { INFRASTRUCTURE FAILURE }\end{array}$ & $\begin{array}{l}\text { EXPOSURE } \\
\text { TO }\end{array}$ & POTENTIAL DERIVED RISKS AND CASCADING EFFECTS \\
\hline $\begin{array}{l}\text { Mobility | Railways |Surface and } \\
\text { underground }\end{array}$ & $\begin{array}{l}\text { Flood and storms can cause } \\
\text { interruption of public and private } \\
\text { transportation }\end{array}$ & $\begin{array}{l}\text { SLR; R: runoff, } \\
\text { flood; } \mathbf{W} \text { : } \\
\text { storms }\end{array}$ & \\
\hline Mobility | Railways | Traffic signs & $\begin{array}{l}\text { Wind can generate failures of } \\
\text { traffic control systems }\end{array}$ & $\begin{array}{l}\text { R: runoff, flood } \\
\text { W: storms }\end{array}$ & \\
\hline $\begin{array}{l}\text { Green and blue infrastructure and } \\
\text { urban equipment I Several } \\
\text { components (trees, street lighting) }\end{array}$ & $\begin{array}{l}\text { Collapse of trees } \\
\text { Damage and collapse }\end{array}$ & $\begin{array}{l}\text { R: runoff, flood } \\
\text { W: storms }\end{array}$ & $\begin{array}{l}\text { Urban drainage: obstruction of components (e.g., inlets, sewers); Electrical } \\
\text { energy: damage to equipment and lines; Mobility (road, rail): traffic } \\
\text { disturbances and interruptions; Communication: damage to equipment } \\
\text { and lines }\end{array}$ \\
\hline
\end{tabular}



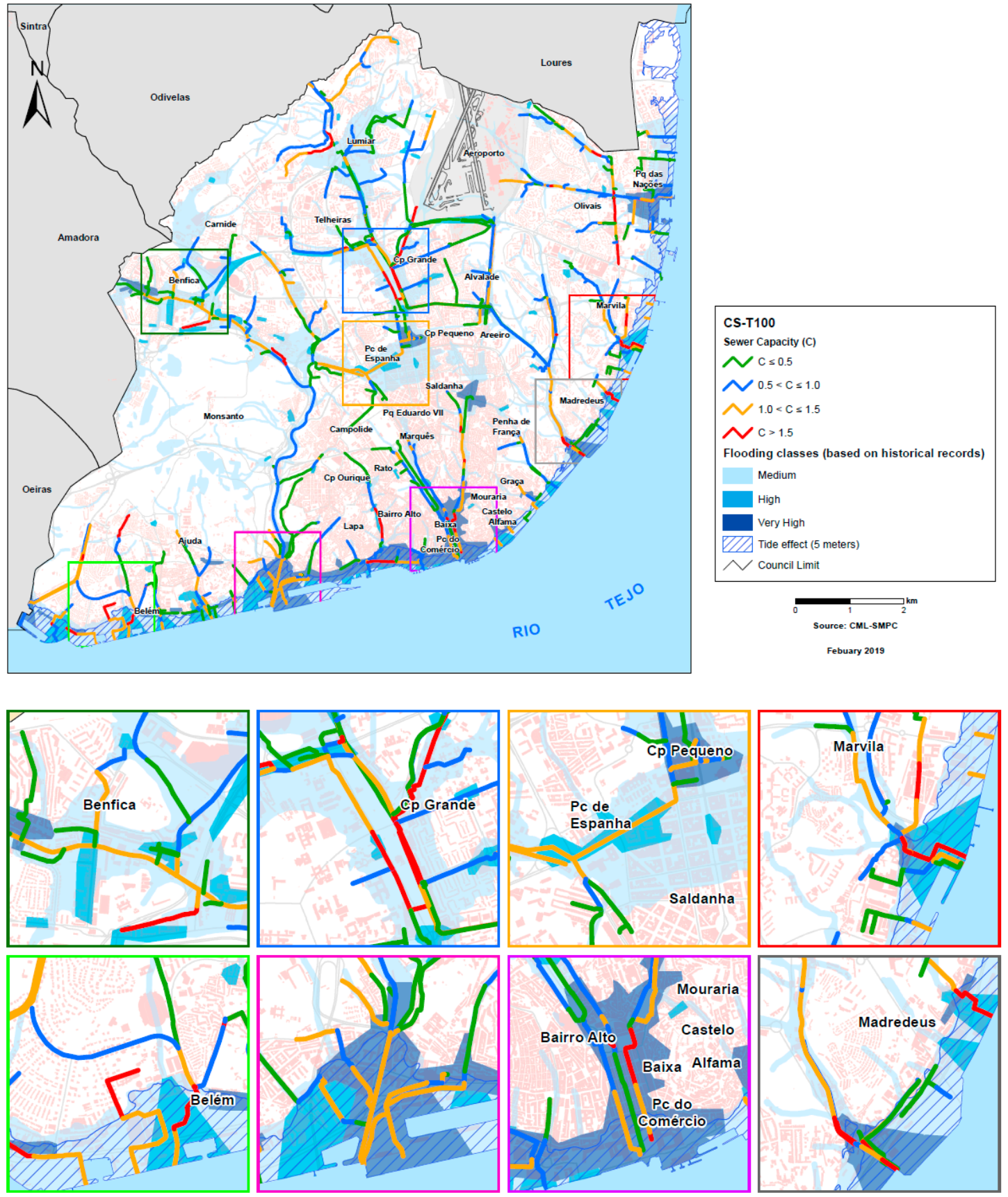

Figure 3. Use of sewer capacity at primary sewers (current situation (CS)-T100) and flood hazards based on historic observations.

\subsection{Main Results for Current Situation and Business as Usual with Climate Change}

Comparing the results of model 1 (1D GIS based), for the current situation (CS as baseline) and climate change scenarios (BAU, business as usual), i.e., BAU-CS, for each return period, allows estimating the effects of climate change scenarios simulated for the whole city, despite the limitations previously mentioned. The results show an aggravation in the metric $C$ (use of sewer capacity) as response to increased flows generated, for the three return periods (Figure 4 and Table 5). The urban drainage overall performance decreases $8.6 \%, 7.8 \%$ and $10.0 \%$, respectively for the return periods 10 , 20 and 100 years. These percentages correspond to the sum of the values of classes "high" and "very high" from Table 5 and represent the relative increase in sewer length where capacity exceeds full pipe capacity and is a proxy of the relative effect of the simulated climate change scenarios. 


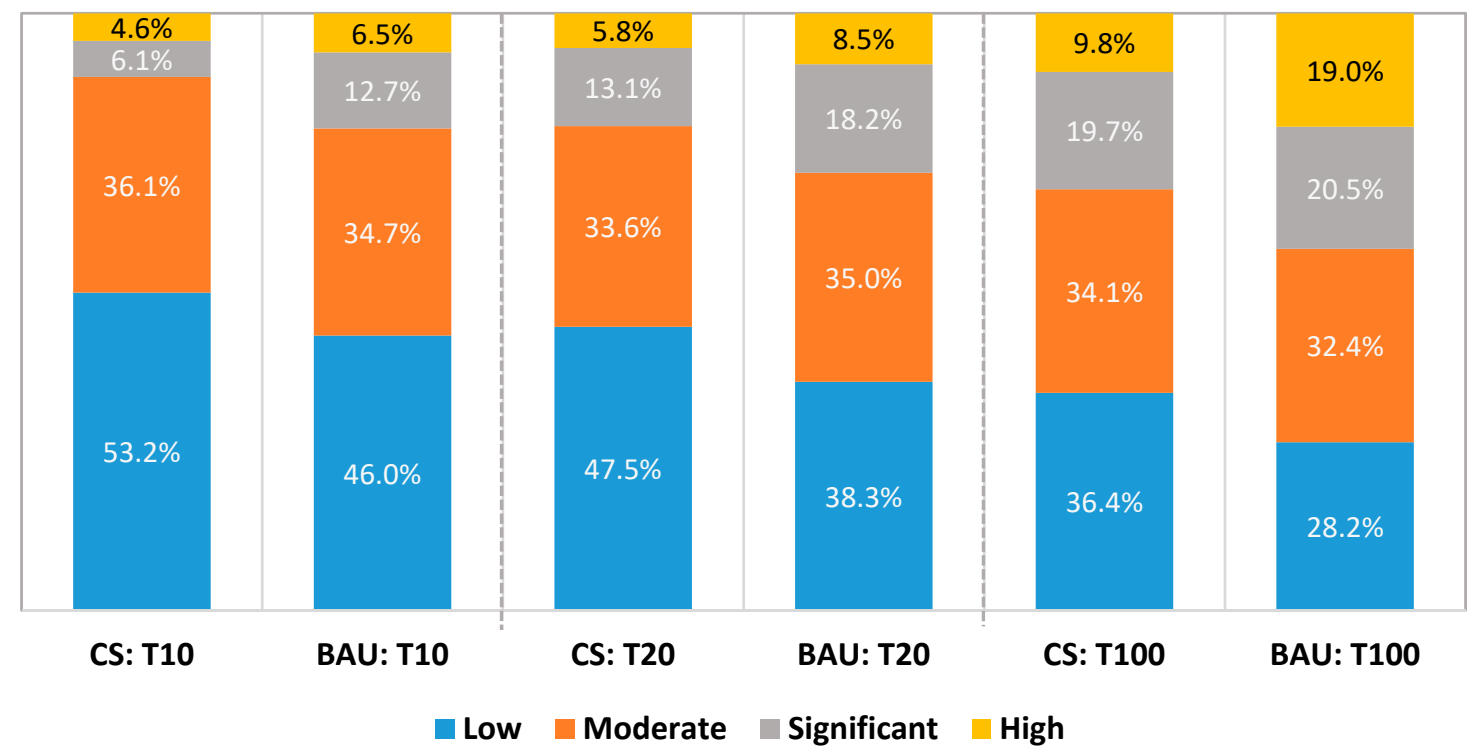

Figure 4. Citywide results for use of sewer capacity (model 1D GIS): CS and business as usual (BAU) situations.

Table 5. Citywide results for use of sewer capacity (model 1D GIS): comparison between CS and BAU.

\begin{tabular}{lcccc}
\hline \multirow{2}{*}{ C Range } & Use of Sewer & \multicolumn{3}{c}{ Return Period (\%(BAU-CS)) } \\
& Capacity & T010 & T020 & T100 \\
\hline$C \leq 0.5$ & Low & -7.2 & -9.2 & -8.3 \\
$0.5<C \leq 1.0$ & Moderate & -1.4 & +1.4 & -1.7 \\
$1.0<\mathrm{C} \leq 1.5$ & High & +6.7 & +5.1 & +0.8 \\
$\mathrm{C}>1.5$ & Very high & +1.9 & +2.7 & +9.2 \\
\hline
\end{tabular}

For Lisbon downtown catchments J and L, results of the assessment of flood water level hazard using model 2 (Table 6) show a predominance of very low water levels and a slight increase in flooded areas associated with climate change scenarios (BAU). The apparent small magnitude in the effect of precipitation and sea level increase is explained by the aggregation in hazard classes, a factor not affected by variations in level within the classes of hazard, which is observed in detailed simulation results such as the example in Figure 5, the map showing the results at a critical time step, for T100. The overall magnitude of this hazard is identical in BAU and CS simulation results.

Table 6. Catchments J and L results for flood water level hazard (model 1D/2D): CS and BAU situations summary.

\begin{tabular}{ccccccccccc}
\hline $\begin{array}{c}\text { Flood Water } \\
\text { Level }(\mathbf{m})\end{array}$ & Hazard & \multicolumn{2}{c}{ T010 $(\mathbf{\%}) *$} & \multicolumn{2}{c}{ T020 (\%)* } & \multicolumn{2}{c}{ T100 (\%)* } & \multicolumn{2}{c}{$\Delta(\mathbf{B A U}-\mathrm{CS})(\%)$} \\
Class & CS & BAU & CS & BAU & CS & BAU & T010 & T020 & T100 \\
\hline $\mathrm{d} \leq 0.2$ & Very low & 96.5 & 96.0 & 95.8 & 95.4 & 93.1 & 92.4 & -0.57 & -0.47 & -0.67 \\
$0.2<\mathrm{d} \leq 0.4$ & Low & 2.9 & 3.4 & 3.5 & 3.9 & 5.9 & 6.4 & +0.53 & +0.40 & +0.58 \\
$0.4<\mathrm{d} \leq 0.6$ & Moderate & 0.5 & 0.5 & 0.5 & 0.6 & 0.8 & 0.8 & +0.07 & +0.05 & +0.06 \\
$0.6<\mathrm{d} \leq 0.8$ & High & 0.1 & 0.1 & 0.1 & 0.1 & 0.2 & 0.3 & -0.02 & +0.02 & +0.03 \\
$0.8<\mathrm{d} \leq 1.0$ & Very high & 0.0 & 0.0 & 0.0 & 0.0 & 0.0 & 0.0 & -0.01 & +0.00 & +0.00 \\
\hline
\end{tabular}

$\left(^{*}\right)$ Percentage in each class.

The results for hazard to pedestrians are shown in Table 7. The magnitude of this hazard increases for all return periods, reaching around 4.0, 3.6 and 2.9 for the T010, T020 and T100 return periods, showing a slight decrease with the return period. Results for the assessment of hazard to vehicles (Table 8), follow a similar trend. 


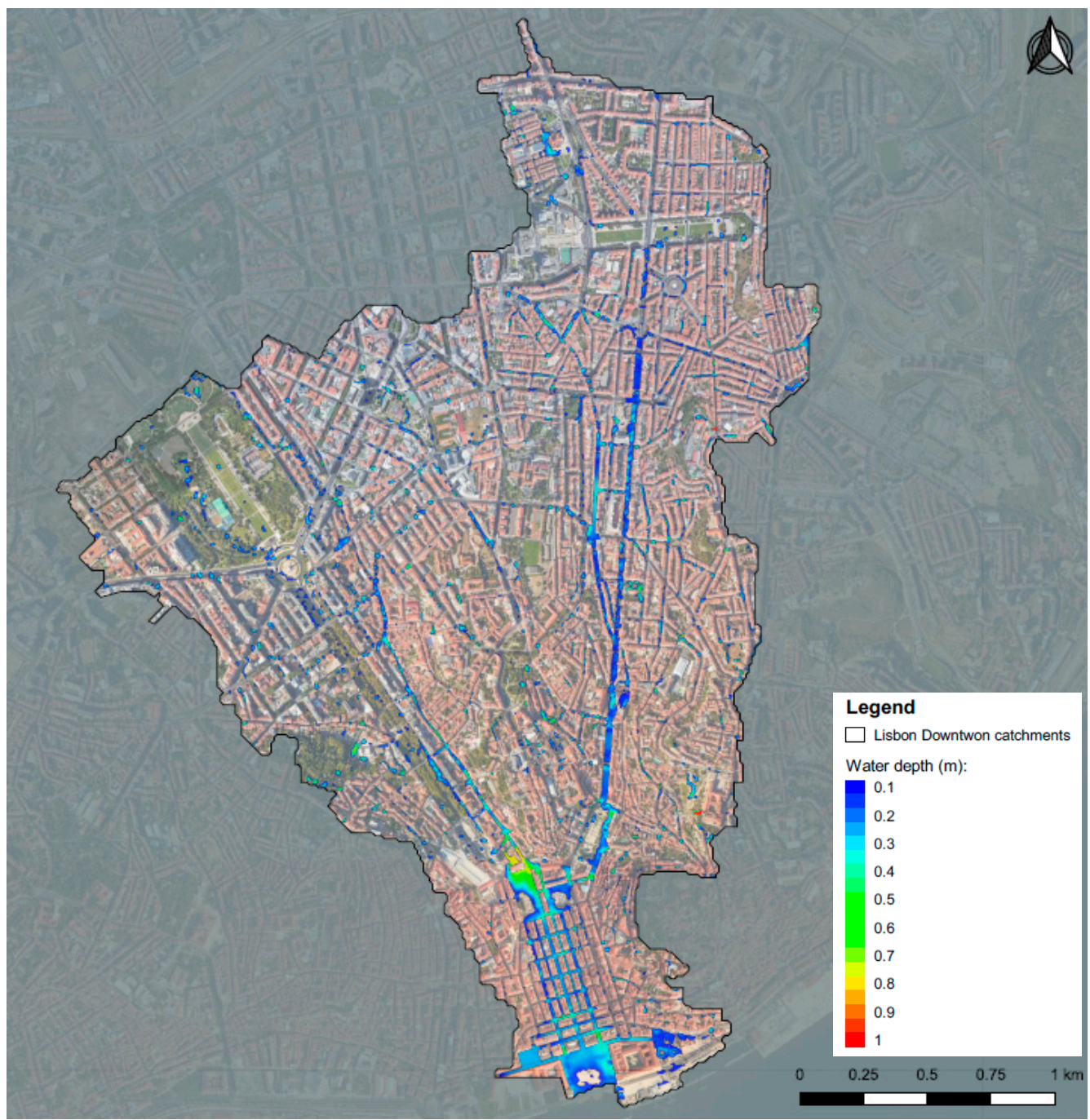

Figure 5. Results from model 1D/2D, catchments J and L. for the BAU situation (T100): water level at a critical time.

Table 7. Catchments J and L results for hazard to pedestrians (model 1D/2D): CS and BAU situations summary.

\begin{tabular}{ccccccccccc}
\hline \multirow{2}{*}{ HR Range } & \multirow{2}{*}{ Hazard } & \multicolumn{2}{c}{ T010 (\%)* } & \multicolumn{2}{c}{ T020 (\%) } & \multicolumn{2}{c}{ T100 (\%) } & \multicolumn{2}{c}{$\Delta$ (BAU-CS) (\%) } \\
& Class & CS & BAU & CS & BAU & CS & BAU & T010 & T020 & T100 \\
\hline$H R \leq 0.75$ & Low & 79.3 & 75.2 & 76.0 & 72.5 & 67.3 & 64.4 & -4.0 & -3.6 & -2.9 \\
$0.75<H R \leq 1.25$ & Moderate & 18.5 & 21.7 & 20.9 & 23.5 & 26.9 & 28.9 & +3.2 & +2.6 & +2.0 \\
$1.25<H R \leq 2$ & Significant & 2.2 & 3.0 & 3.0 & 3.9 & 5.7 & 6.6 & +0.8 & +0.9 & +0.8 \\
$H R>2$ & Extreme & 0.1 & 0.1 & 0.1 & 0.1 & 0.2 & 0.2 & 0.0 & 0.0 & 0.0 \\
\hline
\end{tabular}

$\left(^{*}\right)$ Percentage in each class.

Considering the results from the methods applied, it can be concluded that current situation is already unfavourable in terms of flooding frequency in various locations in Lisbon, but the magnitude of the hazards is generally low. Generally, these results are in alignment with available historical observations. The overlapping of the maps for the use of sewer capacity ((model 1D GIS) with results of model 1D/2D, for catchments J and L, confirms the most overloaded parts of the sewer network.

The climate change scenarios simulated do not impose significant increase in the magnitude of flood related hazards to properties and infrastructures, pedestrians and vehicles. Consequently, implications for the mobility and to waste sectors, compared to current situation, are expected to be low. 
Table 8. Catchments J and L results for hazard to vehicles (model 1D/2D): CS and BAU situations summary.

\begin{tabular}{|c|c|c|c|c|c|c|c|c|c|c|}
\hline \multirow{2}{*}{ Class Range } & \multirow{2}{*}{$\begin{array}{c}\text { Hazard } \\
\text { Class }\end{array}$} & \multicolumn{2}{|c|}{ T010 (\%)* } & \multicolumn{2}{|c|}{ T020 (\%)* } & \multicolumn{2}{|c|}{ T100 (\%)* } & \multicolumn{3}{|c|}{$\Delta($ BAU-CS) $(\%)$} \\
\hline & & $\mathrm{CS}$ & BAU & $\mathrm{CS}$ & BAU & $\mathrm{CS}$ & BAU & T010 & T020 & T100 \\
\hline $\begin{array}{l}\mathrm{D} \leq 0.28 \text { and } D \times|\vec{v}| \\
\leq 0.40\end{array}$ & Low & 80.3 & 76.9 & 77.8 & 74.9 & 70.5 & 68.3 & -3.4 & -2.9 & -2.3 \\
\hline $\begin{array}{c}\mathrm{D} \leq 0.28 \text { and } \\
0.40<D \times|\vec{v}| \leq 0.55\end{array}$ & Moderate & 13.2 & 15.2 & 14.5 & 16.0 & 18.1 & 18.9 & +1.9 & +1.5 & +0.8 \\
\hline $\begin{array}{c}D>0.28 \text { or } \\
D \times|\vec{v}|>0.55\end{array}$ & High & 6.5 & 7.9 & 7.7 & 9.0 & 11.3 & 12.8 & +1.4 & +1.4 & +1.5 \\
\hline
\end{tabular}

$\left({ }^{*}\right)$ Percentage in each class.

\subsection{Main Results for Selected Adaptation Strategies and Climate Change Scenarios}

The three adaptation strategies selected for testing the proposed methodology, are some of those that can be simulated by hydraulic modeling and considered to be relevant by the stakeholders. These strategies are proposed in the Lisbon Master Plan 2016-2030 [36]. Even during risk identification, as presented in this paper, it is valuable to assess the impact of adaptation strategies in the flood related hazards.

The first strategy, CAS1-Adaptation of green infrastructure, corresponds to a significant increase of the total green area in the city (Figure 6). The second strategy, CAS2-Peak flow attenuation through the construction of two retention basins, includes the construction of two small retention basins, one of which has the main purpose of retaining solids (Figure 7).

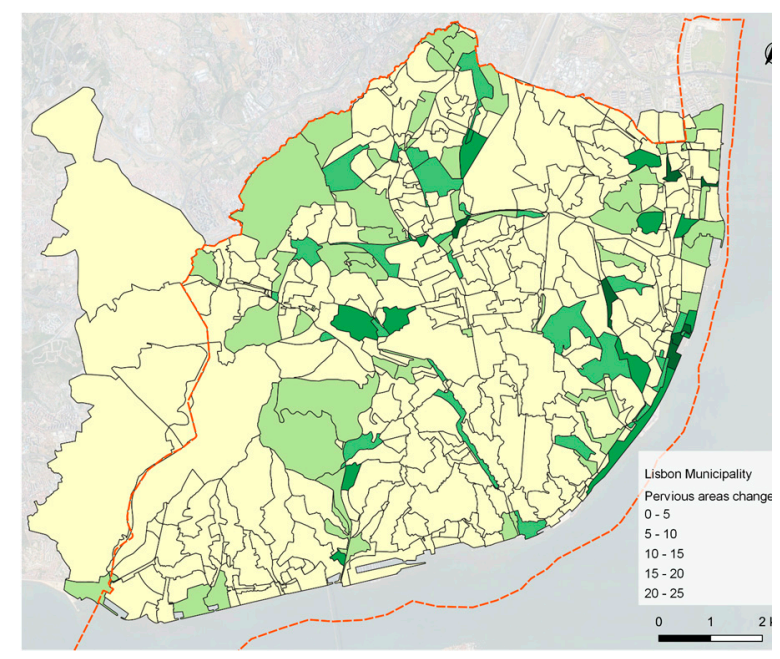

Figure 6. Green areas relative change: \% increase from BAU to CAS1.

The third strategy modelled, CAS3 - Construction of new components in drainage system, proposes the construction of a large interception tunnel and improvement in the inlets to the sewer network (Figure 8).

The three strategies were simulated with the citywide simplified model 1 but for the detailed model 2 of catchments J and L, only CAS3 is relevant.

Results of model 1 (1D GIS based), for BAU, CAS1, CAS2 and CAS3, for each return period, for the metric $C$, use of sewer capacity, are given in Figure 9, in terms of the relative variations to CS. The results show an aggravation in the metric $\mathrm{C}$ for BAU situation as presented previously as response to increased flows generated in the scenarios of climate change, for the three return periods. CAS1 has only some effect in the areas downstream of the catchments but even in those areas the reduction is limited, since the area upstream to the basins is small and the basin volumes are also small. CAS2 
has no substantial influence and results are similar for all return periods. This is attributed to the small influence of the green areas on the hydrological processes for intense rainfall events. CAS3 is the only strategy contributing to decrease the length of sewers in the most severe class. However, since the effect is mainly expected in the areas downstream of the tunnels, the effect is not evident when evaluated for the whole city. In Table 9, the results for the areas downstream of the tunnels are presented and the effect of the tunnels is clearly effective in the reduction of flooding.

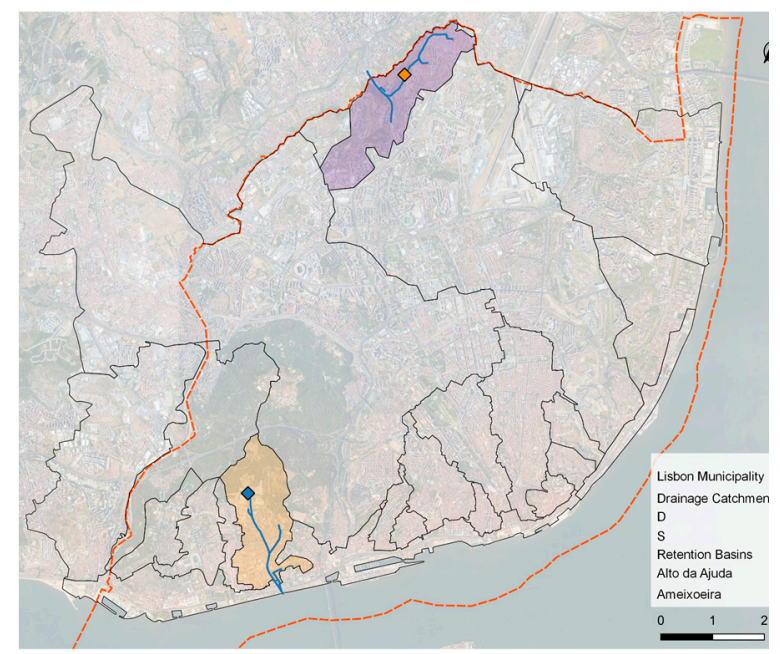

Figure 7. Location of the retention basins planned in the CAS2.

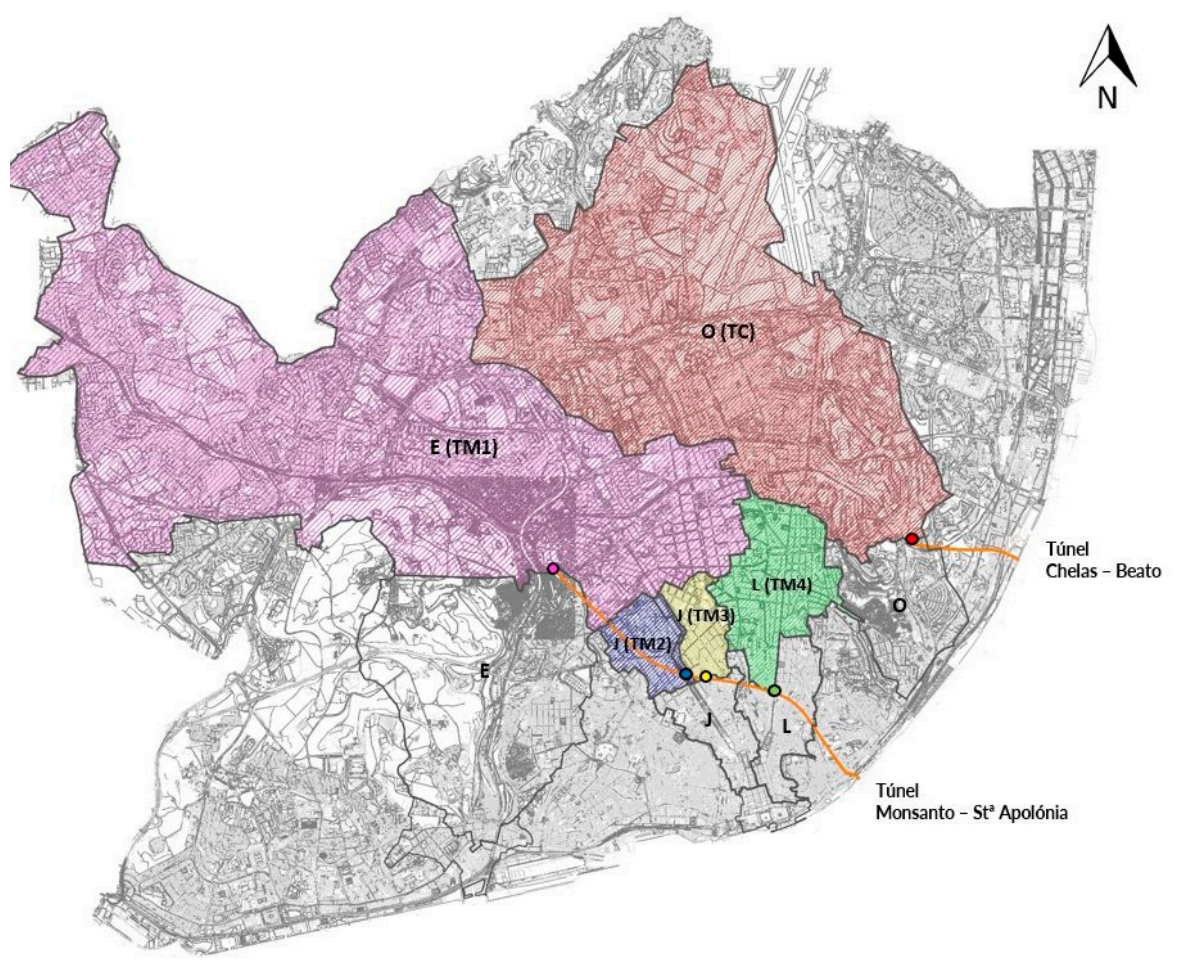

Figure 8. Tunnels: associated drainage catchments and intersection locations [37].

Globally, the results indicate that from the three strategies analysed, only CAS3 has a significant effect on flood related hazards and is limited to the areas downstream of the tunnels. 


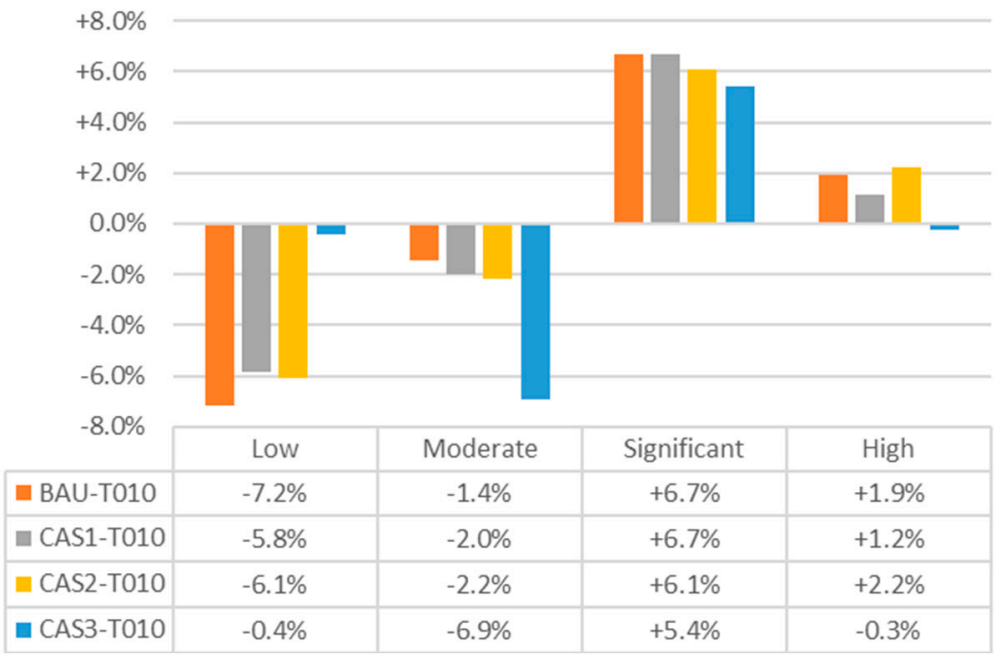

(a) Use of sewer capacity: results for T010

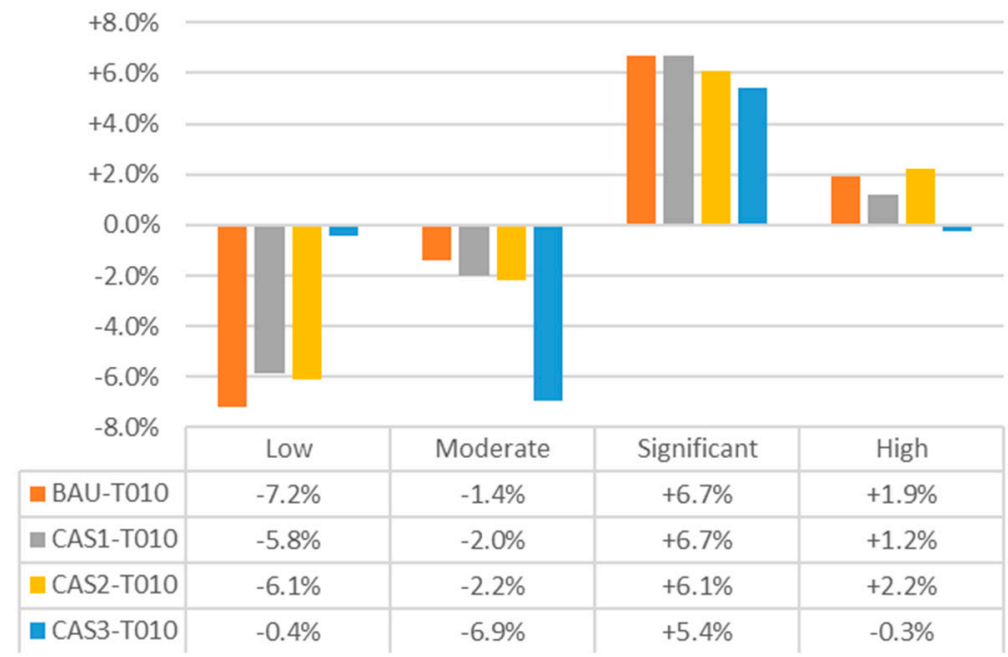

(b) Use of sewer capacity: results for T020

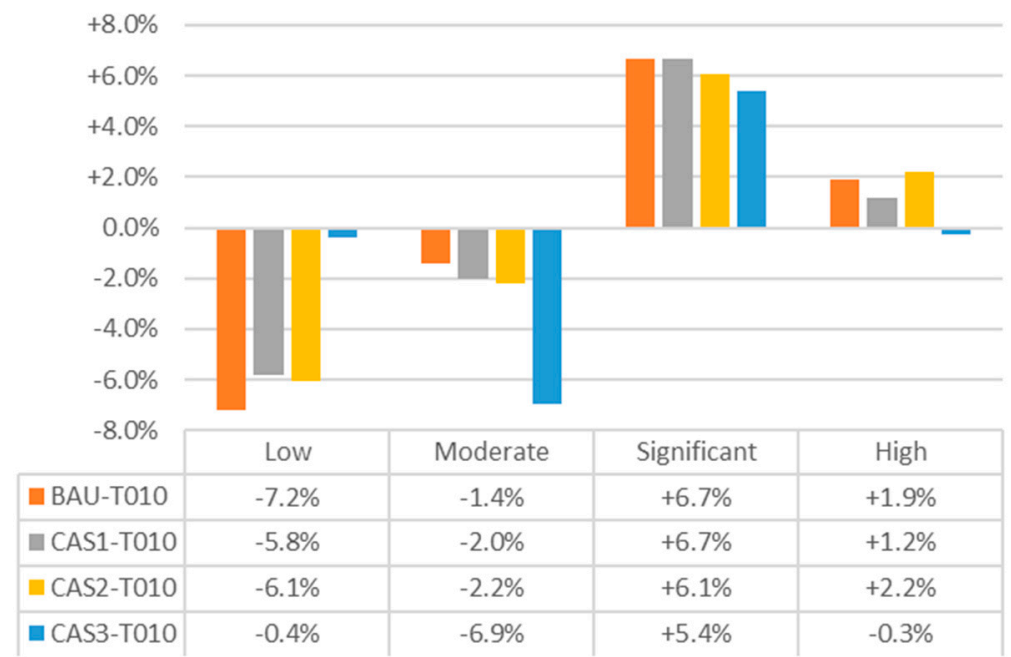

(c) Use of sewer capacity: results for T100

Figure 9. Citywide results for use of sewer capacity (model 1D GIS): results for BAU and CAS situations compared with CS. 
Table 9. Results for use of sewer capacity (model 1D GIS) in catchments downstream of the tunnels: comparison between CS and CAS3.

\begin{tabular}{llccc}
\hline \multirow{2}{*}{ C Range } & Use of Sewer & \multicolumn{3}{c}{ Return Period (\%(CAS3-CS)) } \\
& Capacity & T010 & T020 & T100 \\
\hline$C \leq 0.5$ & Low & +36.0 & +41.3 & +38.3 \\
$0.5<C \leq 1.0$ & Moderate & -36.6 & -35.1 & -30.6 \\
$1.0<\mathrm{C} \leq 1.5$ & High & +1.4 & -4.4 & -8.3 \\
$C>1.5$ & Very high & -0.8 & -1.8 & +0.6 \\
\hline
\end{tabular}

The effect of CAS3 on the catchments J and L is also beneficial but is not improving significantly under the current situation. This can be explained by the existence of duckbill tidal valves that require a certain pressure upstream to allow flows downstream to receiving waters. The CAS-3 results for downtown catchments detailed modelling (model 2) show the increase of the carrying capacity at the downstream sewers as the main effects of construction of the diversion tunnels, as obtained for the 1D GIS Model simulations. Nevertheless, in some cases, considerable water depths still occur.

The results for flood hazard to pedestrians show a slight decrease for all return periods. The results for the hazard to vehicles follows a similar trend.

\section{Final Remarks}

Risk identification is a key phase for risk-based approaches as well as to assessing resilience. Limitations in data and in ready-to-use tools often limits the development of these assessments. The methodology applied allows us to proceed with the spatial characterization of the flood related hazards and exposure of essential functions and services providers in urban areas, as a first step to support the assessment of the resilience to specific hazards, taking into account interdependencies and cascading effects. The combination of methods and existing data can add benefits often not obtained with more sophisticated methods and data. The combination of data and knowledge from different sources with dual modelling approaches can provide helpful results about the magnitude hazards, using metrics that relate with the urban functions and corresponding services, for different situations and scenarios.

An encouraging outcome of the methodology is the understanding achieved by stakeholders that are not familiar with water issues, about the relevance of flood related hazards for their modus operandi and the value of information they could obtain from other stakeholders to increase the resilience and reliability of their services.

The results obtained for the situations analysed modified the beliefs of involved people about the effect of some strategies to reduce flooding, while improving their understanding of hydrological and hydraulic processes and their relevance for managers and operators in Lisbon.

Areas for improvement include procedures to record flooding events and corresponding meteorological information, information on sewer network operational condition promotion of closer collaboration between stakeholders. Tools such as hydraulic models need to be recognized as effective in supporting current systems management.

The characterization of the hazards is instrumental to the adaptation of different sectors and, in this application, allowed us to realize that despite climate change impacts, the current situation is already affecting a number of city functions and services.

Author Contributions: M.d.C.A. supervised this study, developed the methodology and its application, analysed the results, drafted the manuscript and finalized it. M.J.T., M.M., J.B. and R.L. contributed to application of the methodology and analysis of the results, and provided suggestions on the draft manuscript. M.J.T. and M.M were responsible by undertaking data collection and overall mapping in ArcMap ${ }^{\mathrm{TM}}$ software. J.B. and R.L. were responsible by undertaking the simulations of the drainage systems. All authors have read and agreed to the published version of the manuscript.

Funding: This research was funded by EUROPEAN UNION'S HORIZON 2020 RESEARCH AND INNOVATION PROGRAM, call H2020-DRS-2015 under the Grant Agreement number 700174 and acronym RESCCUE. 
Acknowledgments: The work presented was developed within the EU H2020 RESCCUE project - Resilience to Cope with Climate change in Urban areas. Acknowledgment is due to Portuguese RESCCUE partners, as well as to all external contributors.

Conflicts of Interest: The authors declare no conflict of interest.

\section{References}

1. UN. Transforming Our World: The 2030 Agenda for Sustainable Development. A/RES/70/1 United Nations. 2015. Available online: https://sustainabledevelopment.un.org/content/documents/ 2125203020Agenda20for20Sustainable20Development20web.pdf (accessed on 10 January 2020).

2. Rogers, C.D.F. Engineering future liveable, resilient, sustainable cities using foresight. Proc. Inst. Civ. Eng. Civ. Eng. 2018, 171, 3-9. [CrossRef]

3. Elmqvist, T.; Andersson, E.; Frantzeskaki, N.; McPhearson, T.; Olsson, P.; Gaffney, O.; Folke, C. Sustainability and resilience for transformation in the urban century. Nat. Sustain. 2019, 2, 267-273. [CrossRef]

4. IPCC. Global Warming of $1.5^{\circ} \mathrm{C}$. Summary for Policymakers; Intergovernmental Panel on Climate Change: Geneva, Switzerland, 2018.

5. WEF. The Global Risks Report 2019, 14th ed.; World Economic Forum: Geneva, Switzerland, 2019.

6. UN-Habitat City Resilience Profiling Programme. Guide to the City Resilience Profiling Tool. United Nations Human Settlements Programme (UN-Habitat). 2018. Available online: http://urbanresiliencehub.org/wpcontent/uploads/2018/07/CRPT-Guide-18.07-Pages.pdf (accessed on 24 September 2018).

7. IPCC. 5th Assessment Report; Intergovernmental Panel on Climate Change: Geneva, Switzerland, 2014.

8. Kachali, H.; Storsjö, I.; Haavisto, I.; Kovács, G. Inter-sectoral preparedness and mitigation for networked risks and cascading effects. Int. J. Disaster Risk Reduct. 2018, 30, 281-291. [CrossRef]

9. Serre, D.; Heinzlef, C. Assessing and mapping urban resilience to floods with respect to cascading effects through critical infrastructure networks. Int. J. Disaster Risk Reduct. 2018, 30, 235-243. [CrossRef]

10. Velasco, M.; Russo, B.; Martínez, M.; Malgrat, P.; Monjo, R.; Djordjevic, S.; Fontanals, I.; Vela, S.; Cardoso, M.A.; Buskute, A. The RESCCUE Project: RESilience to cope with Climate Change in Urban arEas-a multisectorial approach focusing on water-The RESCCUE Project. Water 2018, 10, 1356. [CrossRef]

11. Pearson, J.; Punzo, G.; Mayfield, M.; Brighty, G.; Parsons, A.; Collins, P.; Jeavons, S.; Tagg, A. Flood resilience: consolidating knowledge between and within critical infrastructure sectors. Environ. Syst. Decis. 2018, 38, 318-329. [CrossRef]

12. Burns, P.; Hope, D.; Roorda, J. Managing infrastructure for the next generation. Autom. Constr. 1999, 8, 689-703. [CrossRef]

13. Pregnolato, M.; Ford, A.; Glenis, V.; Wilkinson, S.; Dawson, R. Impact of Climate Change on Disruption to Urban Transport Networks from Pluvial Flooding. J. Infrastruct. Syst. 2017, 23, 1-13. [CrossRef]

14. Otto, A.; Kellerman, P.; Thieken, A.H.; Costa, M.M.; Carmona, M.; Bubeck, P. Risk reduction partnerships in railway transport infrastructure in an alpine environment. Int. J. Disaster Risk Reduct. 2019, 33, 385-397. [CrossRef]

15. Martínez, E.; Gómez, M.; Russo, B.; Djordjevic, S. A new experiments-based methodology to define the stability threshold for any vehicle exposed to flooding. Urban Water J. 2017, 14, 930-939. [CrossRef]

16. Martínez, E.; Russo, B.; Gómez, M.; Plumed, A. An approach to the modeling of stability of waste containers during urban flooding. J. Flood Risk Manag. 2020, 13, 1-18. [CrossRef]

17. Hammond, M.J.; Chen, A.S.; Djordjević, S.; Butler DMark, O. Urban flood impact assessment: A state-of-the-art review. Urban Water J. 2015, 12, 14-29. [CrossRef]

18. Rosenzweig, B.R.; McPhillips, L.; Chang, H.; Cheng, C.; Welty, C.; Matsler, M.; Iwaniec, D.; Davidson, C.I. Pluvial flood risk and opportunities for resilience. Wires Water 2018, 5, 1-18. [CrossRef]

19. Evans, B.; Chen, A.; Djordjevic, S.; Webber, J.; Almeida, M.C.; Morais, M.; Telhado, M.J.; Silva, I.; Duarte, N.; Martínez-Gomariz, E.; et al. Impact Assessments of Multiple Hazards in Case Study Areas with Adaptation Strategies; RESCCUE Project: Barcelona, Spain, 2020.

20. INE. Censos 2011 Resultados Definitivos-Portugal. In Census 2011 Definitive Results; National Statistics Institute: Lisbon, Portugal, 2012. 
21. CML. The economy of Lisbon in numbers 2014 (A economia de Lisboa em números 2014). Available online: http://observatorio-lisboa.eapn.pt/ficheiro/Lisboa_em_numeros_2014_final_01.pdf (accessed on 20 April 2017).

22. Telhado, M.J.; Baltazar, S.; Fernandes, F.; Cardoso, M.A.; Almeida, M.C.; Vieira, P.V. Lisbon Municipality Contribution to the Demonstration of the WCSP, RIDB, RRDB, GIS Applications for Risk Assessment in Lisbon; PREPARED project: Nieuwegein, The Netherlands, 2014.

23. The Rockfeller Foundation. Cities Taking Action. How the 100RC Network is Building Urban Resilience. 2017. Available online: http://100resilientcities.org/wp-content/uploads/2017/07/WEB_170720_Summit-report_ 100rc-1.pdf (accessed on 1 February 2020).

24. Silva, M.M.; Costa, J.P. Urban Flood Adaptation through Public Space Retrofits: The Case of Lisbon (Portugal). Sustainability 2017, 9, 816. [CrossRef]

25. Turner, S.F.; Cardinal, L.B.; Burton, R.M. Research Design for Mixed Methods: A Triangulation-based Framework and Roadmap. Organ. Res. Methods 2017, 20, 243-267. [CrossRef]

26. Jick, T.D. Mixing qualitative and quantitative methods: triangulation in action. Adm. Sci. Quartely 1979, 24, 602-611. [CrossRef]

27. Duffy, M.E. Methodological triangulation: A vehicle for merging quantitative and qualitative research methods. J. Nurs. Scholarsh. 1987, 19, 130-133. [CrossRef] [PubMed]

28. Russo, B. (Ed.) Multi-Hazards Assessment Related to Water Cycle Extreme Events for Current Scenario; RESCCUE Project: Barcelona, Spain, 2018.

29. Russo, B. (Ed.) Multi-hazards Assessment Related to Water Cycle Extreme Events for Future Scenarios (Business as Usual); RESCCUE Project: Barcelona, Spain, 2019.

30. Huber, W. Storm Water Management Model (SWMM) Bibliography. Athens, Ga: Environmental Research Laboratory, Office of Research and Development; U.S. Environmental Protection Agency: Washington, DC, USA, 1985.

31. VAW. BASEMENT-Basic Simulation Environment for Computation of Environmental Flow and Natural Hazard Simulation. Version 2.8; ETH Zurich: Zurich, Switzerland, 2018.

32. Hosseini, S.; Barker, K.; Ramirez-Marquez, J.E. A review of definitions and measures of system resilience. Reliab. Eng. Syst. Saf. 2016, 145, 47-61. [CrossRef]

33. Defra, E.A. Flood Risk Assessment Guidance for New Development. Phase 2 Framework and Guidance for Assessing and Managing Flood Risk for New Development-Full Documentation and Tools; Defra and Environment Agency: London, UK, 2005.

34. Antunes, C.; Catita, C.; Rocha, C. Estudo de Avaliação da Sobrelevação da Maré-Determinação da Cartografia de Inundação e Vulnerabilidade da Área Ribeirinha de Lisboa Afetada Pela Sobrelevação da Maré Como Consequência da Futura Subida do Nível Médio do Mar. Relatório Técnico EMAAC; Câmara Municipal de Lisboa: Lisbon, Portugal, 2017; 46p.

35. Paradinas, C.; Monjo, R.; Gaitán, E.; Carravilla, C.; Torres, L. Projection of Climate Extremes in the City of Lisbon: A Comparative Study; RESCCUE Project: Barcelona, Spain, 2019.

36. Hidra, Engidro, Bluefocus. Plano Geral de Drenagem de Lisboa 2016-2030; Câmara Municipal de Lisboa: Lisbon, Portugal, 2015.

37. Hidra. Tender Documents for the Construction Works of the Drainage Tunnels and Associated Interventions in Lisbon; Câmara Municipal de Lisboa: Lisbon, Portugal, 2018.

(C) 2020 by the authors. Licensee MDPI, Basel, Switzerland. This article is an open access article distributed under the terms and conditions of the Creative Commons Attribution (CC BY) license (http://creativecommons.org/licenses/by/4.0/). 